\title{
The Role Of Trade And Industry Department (Disperindag) As Muhtasib In Traditional Market Supervision (Field Study In Bunder Market Sragen)
}

\author{
M. Fajar Pramono ${ }^{1}$, Mulyono Jamal' ${ }^{2}$ Intan Muthoharoh ${ }^{3}$ \\ \{email: Fajarpramono@gontor.unida.ac.id ${ }^{1}$, email: Mulyonojamal@gontor.unida.ac.id ${ }^{2}$, email: \\ Intanmuthoharoh@gontor.unida.ac.id $\left.{ }^{3}\right\}$ \\ Universitas Darussalam Gontor, Jl. Demangan Siman Ponorogo Jawa Timur ${ }^{1}$, \\ Universitas Darussalam Gontor, Jl. Demangan Siman Ponorogo Jawa Timur ${ }^{2}$, \\ Universitas Darussalam Gontor, Jl. Demangan Siman Ponorogo Jawa Timur ${ }^{3}$,
}

\begin{abstract}
There are limits that regulate in doing muamalah, in order nobody feel lost and dominate another. Since ancient times, the market is supervised by supervisor to stabil the activities inside it. This research aims to determine the role of the industry and trade department (disperindag) in overseeing traditional markets, This study uses the type of qualitative research and type of research "case study". Based on this research, consider that the industry and trade department has not done yet its role as well as possible. For improving the function and role of trade department at Sragen, the researcher also went to the best market in supervising at Indonesia, it was trade department at purwokerto because they have made the good supervision at Manis Market at Purwokerto. And asking the advice and opinion of province trade department at semarang about the role of both (trade department of sragen and porwokerto).
\end{abstract}

Keywords: Industry andTrade Department, Muhtasib and Traditional Markets.

\section{Introduction}

According to Muamalah Maliyah, every man must know what does he need held control to regulate the stability and done all activities. The market is a place where consumers[1] very drape daily needs, In Islamic supervision, the role of muhtasib has been played by the Prophet, Khulafa and the Companions in carrying out the State Oversight. In this era, the role of muhtasib played by Government supervisory bodies is very influential for all institutions.[2]

Without having a clear concept, the state will have difficulties in controlling and monitoring the development of the country. Although there is no hisbah term on a special and similar to the system of the times of prophet this has been existing in Indonesia, but a form of market supervision have been done a lot. Because Islamic Economic lot contribute and developing rapidly, then need handling more, can be done in form research and conference.[3]

\section{Content}

In researching a role in market surveillance, research methods that will be used are Qualitative. Judging from its objectives, case studies are one of the qualitative methods that are carried out based on trust, knowledge and differences in values in the field.[4] This was supported by Yin statement which defines that case studies are methods used to examine phenomena that occur in a person and become life experiences. [5] For the method of collecting data, this research uses three methods. That is the method of observation, interview and documentation.[6] The deployment will be done by observing the condition of the Bunder market and analyze the behavior of the sellers and buyers as well as the surrounding communities.

The second method is interview. this method is applicable to obtain information from respondents, supervisors and persons involved in the activities of the market every day. Some objects of research will be in the interview include parts of the Department of Commerce to portray the role of watchdog, guard security guard market, sellers, buyers and the public about who passed thatch, 
even being in the Bunder Market at every day. And the excess that is found to getting many data from the first source, although have plenty of emotion.[7]

The history of trade in the world begins when humans lived in primitive times, by exchanging between one item and another.[8] So if there are people who want to possess some goods, the person must redeem use what the goods needed by the second.As the exchange activities progressed, several obstacles were found to be felt by the community, for example, the first example owned rice and wanted to be exchanged for a chicken meat, the target was people who owned chicken and needed rice to exchange. And the second is the stuff that men become the object of exchange should be divided, though not all persons have the same goods. Another example, if two kilos of sugar that is equivalent to a piece of clothing. If both are exchanged, then a right was difficult if it changed with a kilo of sugar with half the clothes.Having considered many obstacles in the transaction, finally, since that time people have considered to have a tool exchange unit. Because if there is one unit in the exchange tool, it willmake them easier until finally the trade term appeared.

In the meantime, the definition of trade is a job where there are buyers who buy goods from one place to another, or from one time to another in order to obtain profits.[9] These definitions change and develop along with the changing times that become modern, trade has a broader meaning, namely activities that bridge producers and consumers in buying and selling transactions[10]

So the essence of a sale and purchase agreement is the surrender of ownership rights to an item and the payment must be accompanied by the submission of money, if it does not use money, it is not called a sale and purchase agreement, but barter.

Finally, the Republic of Indonesia Law No. 7 of 2014 on trafficking, defines that trade is the order of the activities associated with the transactions and the goods and services in the country and beyond the borders of the country with a view to transferring the right of goods and services to obtain a reward or compensation.[11] The role of the Trade department in terms of details of the main tasks is as followsthe tasks and functions that were captured became 55 articles in regency regulation Sragen No. 97 of 2016.The service has the task of assisting the regent in carrying out government affairs in the field of industry and trade which are the authority of the region and the task of assistance assigned to the region.[12]

1. Formulation of industrial and trade policies

2. Implementation of coordination in industrial and trade policies

3. Implementation of industrial and trade policies

4. Implementation of evaluation and reporting in the field of Industry and Trade

5. Implementation of secretariat functions.

6. Implementation of other official functions provided by the leadership, in accordance with their duties and functions.

Then assorted assumption states that trade activities are the main activities as a mover in making economic development, which in it contains the power of job creation, increased production, income generation and others. As the prime mover of the economy, trade not only about the limit of economic activity by transaction charcoal or discouraged, but it also about the implementation of economic activitymust comply with the concept of regulation in the field of trade and in accordance with the idealsnamely creating a just and prosperous society as mentioned in the opening text of the 1945 Constitution.

The supervision at Rasulullah term is called as hisbah. Specific role of hisbah in the economy intended the role of hisbah institution which is directly related to economic activity in an Islamic state. Among them are:

1. Ensuring that the market serve halal product and in accordance with Shari'a.

2. Eradicate fraud, deception, and abuse of goods and prices[13]

3. Prevent usury.

4. Fighting Ihtikar

5. Set at price (tas'ir)

The explaination that has been discussed that the duties which accordance among muhtasib with industry and trade department is Maintaining government facilities in the Market, it is shown by management of regional property or wealth and service for the procurement of goods or services in the service environment in traditional market,Monitor the cleanliness of the premise and health of the 
population, it is related with the duties of trade department which carrying out the formulation, coordination, implementation, and monitoring traditional market. So, Eradicate fraud, deception, and fraud against price that has been done by muhtasib, it is accordance with the duties of trade department which Coordinating monitoring, evaluation and reporting covering trade coaching, services and metrology, promotion, trade development and services and trade distribution supervision.Set prices (tas'ir) and Prevent oppression and persecution on the market also be done by muhtasib, it is accordance with the duties of trade department in the Field of Trade Development, the part that implements contracting in the stabilization of prices of essential goods and essential goods. The effort of government in controlling stability and for the running of state activities that are in effect. Because in truth, a country will not escape from three important things, they are: Law, Economy and politics.

The task of the state to implement the Hisbah system, namely direct checking of size and weight, quality control, and standardization. It is also the duty of the State to prohibit the practice of speculation and monopoly. The purpose of hisbah is to protect the public from irregularities, monitor the market so that the life order is guaranteed security and fulfillment of its basic needs.

\section{Result}

The role of Disperindag Sragen as Muhtasib has not been well, but many functions has been done and they have supervised as the supervisor of traditional market by good. Disperindag Purwokerto as the best market supervisor at Indonesia suggested that to have a good role, need to be consistant with the regulation and function and follow the regulation that has been given by SNI (Standar Nasional Indonesia) as quality assurance which regulate all kind of Indonesia standart national. And the centre of province industry and trade department (Disperindag provinsi) said that no worried because either disperindag sragen or purwokerto have had a good supervisor enough. And the research suggest to all trade and indutry department at Indonesia to refer to Hisbah for improving the supervision.

\section{Reference}

[1] Ministry of Education and Culture, "Consumers are users of industrial goods such as clothing, food, etc." Balai Pustaka, p. 750.

[2] R. Noviyanti, "Tinjauan Fungsi Hisbah dalam Kegiatan Perekonomian,” J. Iqtishodia Syari'ah, vol. 2, no. $1,2017$.

[3] A. E.-A. and R. Wilson, Islamic Economics A Short History. Leiden Boston, 2006.

[4] C. Polit, D. \& Beck, Nursing research: Principle and methods, 7th ed. Philadelphia: JB Lippincott Company, 2004.

[5] S. Borbasi, Navigating the maze of nursing research: An interactive learning adventure. Australia: Elsevier., 2004.

[6] J. W. Creswell, Research Design.Qualitative, Quantitative and mix methods approaches. .

[7] J. Sarwono., Metode Penelitian Kuantitatif dan Kualitatif. Yogyakarta: Graha Ilmu, 2006.

[8] F. Hasyim, Commercial Law. Sinar Grafika, 2014.

[9] Kansil, Principal of Indonesian Commercial Law, 2nd ed. Sinar Grafika, 2013.

[10] R. Khairandy., Principal of Indonesian Commercial Law. Yogyakarta: UII Press, 2013.

[11] President of the Republic of Indonesia, "Republic of Indonesia law," p. number 7 of 2014.

[12] Documentation from Disperindag, "regent regulation," Disperindag Sragen, 2016, p. 97.

[13] Jaribah bin Ahmad al-Haritsi, Fikih Ekonomi Umar bin al-Khattab. Khalifa. 